\title{
Multi-unit ownership in franchising: evidence from the fast-food industry in Texas
}

\author{
Arturs Kalnins* \\ and \\ Francine Lafontaine ${ }^{* *}$
}

We use data on all the new restaurants opened in Texas between 1980 and 1995 by seven of the largest nationally franchised fast-food chains to examine empirically the extent of multi-unit ownership in franchised chains and the way in which franchisors allocate the ownership of units among franchisees. We find that individual franchisees are much more likely to be assigned the ownership of a particular new unit the closer their existing units are geographically to the new unit. Further, given distance, franchisees are more likely to be allocated a new franchised unit if they already own units whose markets are contiguous and demographically similar to that of the new unit. Finally, contrary to implications from some explanations for company ownership, we find that franchisors use similar criteria when they decide to retain units under company ownership as when they choose among franchisees.

\section{Introduction}

- Most of the literature on franchising has relied on agency-theoretic and transaction-cost arguments to explain the terms of franchise contracts as well as franchisors' tendency to combine franchising and corporate ownership. ${ }^{1}$ One empirical reality of the franchise relationship that has been overlooked by these perspectives is the tendency of franchisors to allow franchisees to own several units. Yet Kaufmann and Dant (1996), who examined the relationship between multi-unit franchising and chain growth, found that $88 \%$ of the 152 franchised fast-food chains they surveyed included multi-unit franchisees, and they noted that "multi-unit franchising is the modal form of franchising" (p. 355). We show below that in Texas in 1995, 49\% of the franchisees of seven

* University of Southern California; kalnins@usc.edu.

** University of Michigan; laf@umich.edu.

We sincerely thank Robert Picard for his expert assistance and support throughout this project. We are also grateful to Karl Longstreth at the University of Michigan Map Library for his help. We thank Luc Anselin, Steven Berry, Severin Borenstein, Keith Crocker, William Greene, Thomas Holmes, Scott Masten, Stephen Michael, Joanne Oxley, Wendy Petropoulos, Kenneth Train, and Bernard Yeung, and participants at several conferences and seminars at a number of universities for helpful comments and suggestions. Finally, we thank the two referees and the Editor, Ariel Pakes, for their thorough and thoughtful comments, and our respective institutions for financial support. The usual caveat applies.

${ }^{1}$ See, e.g., Lafontaine and Slade (2001) for a review of this literature. 
large national fast-food chains were multi-unit owners, and that these franchisees owned $84 \%$ of all the franchised units in these chains. ${ }^{2}$ Our goal in this article is to explore for the first time how franchisors allocate units across individual franchisees. In other words, given a decision by a franchisor to open a new unit at a particular location, we examine how the franchisor chooses who the owner will be. ${ }^{3}$ Because our analyses are not structural, our results about factors that influence this decision should be interpreted as correlations, not statements about causation. Still, the data patterns have important implications for various theories of franchising that we highlight briefly.

The article is organized as follows. In Section 2 we describe how franchisees become multiunit operators, and we very briefly review the implications of existing theories of franchising as they relate to multi-unit ownership. In Section 3 we present our data and a snapshot of the ownership patterns at the end of our sample period, where this snapshot is the result of the set of decisions we model and assess empirically in Sections 4 and 5 respectively. Section 6 concludes.

\section{Multi-unit ownership and franchising}

- Franchisees become multi-unit owners either by purchasing several individual franchised units over time or, at the outset, via an "area development agreement." Of the seven chains we focus on, Dairy Queen, Pizza Hut, and Taco Bell rely on such agreements in at least some areas in Texas. The other chains in our data, Burger King, McDonald's, Subway, and Wendy's, allow multiple unit ownership to arise only via purchases of individual units. In this case, franchisees must satisfy the chain that they can efficiently run their current set of units before being granted the "right to expand." By contrast, franchisees who obtain an area development agreement are granted the right to establish a typically prespecified number of units in an exclusive territory. Thus, such agreements imply not only multi-unit ownership, but also a high degree of geographical concentration of the developer's units. None of the chains in our data, however, grants any form of exclusive territory to franchisees in their single-unit contract. ${ }^{4}$

From an agency-theoretic perspective, multi-unit ownership is somewhat of an anomaly: if franchising is used because owner-operators have reduced incentives to shirk, then the separation of ownership and control over day-to-day operations implied by multi-unit ownership should be viewed as detrimental to the chain. As an executive at Burger King puts it,

after obtaining five stores [the franchisee] is divorced from the function of store manager. He is then nothing more than a district manager. At ten stores, he is a regional manager ... upon receiving additional stores the licensee's declining personal commitment to growth and operations is guaranteed. (McLamore, 1998, p. 151.)

Of course, multi-unit franchisees might overcome this problem by giving incentives to their store managers directly. However, the resulting dilution in residual claims (now shared potentially among franchisor, franchisee, and store manager), and the fact that the manager does not own the assets (and hence has no reason to care about future returns, as per Lutz (1995)) suggest that multi-unit franchising is likely to be detrimental from a pure incentive perspective.

Other theoretical frameworks within which multi-unit ownership would be detrimental to the chain include the strategic entry-deterrence argument for franchising suggested by Hadfield (1991) and the divisionalization argument for franchising proposed by Baye, Crocker, and Ju (1996). The problem in these cases is that a franchisee's ownership of multiple units within a market reduces his incentives to behave as aggressively as a set of single-unit franchisees would.

${ }^{2}$ This figure goes up to $87 \%$ if we include franchisors among multi-unit owners. See also Kaufmann and Lafontaine (1994), Kaufmann and Kim (1995), and Bradach (1998) for some more related data on multi-unit ownership.

${ }^{3}$ We do not, however, address the location decision itself. Kaufmann, Donthu, and Brooks (2000), for example, discuss location issues in franchising.

${ }^{4}$ For example, the McDonald's franchise agreement explicitly states "[t]his Franchise establishes the Restaurant at the location specified ... [and] no 'exclusive,' 'protected.' or other territorial rights in the contiguous market area of such Restaurant is hereby granted or inferred" (McDonald's Corporation (2003), p. 12). The other chains in this study use similar wording. This contrasts with franchising generally, where most franchisors (73\%), and new franchisors in particular, offer exclusive territories to individual franchisees. See Azoulay and Shane (2001) and Blair and Lafontaine (forthcoming) for more on this.

(c) RAND 2004. 
Finally, multi-unit ownership might be detrimental to the chain if it increases the franchisee's bargaining power or his capacity to behave opportunistically vis-à-vis the franchisor. This will be especially problematic for the franchisor if the franchisee controls a large portion of a given market. Moreover, a single owner of several contiguous units may exercise market power to the detriment of the franchisor. In other words, potential double-marginalization problems are compounded when franchisees control clusters of units. ${ }^{5}$

While all the arguments above imply that multi-unit ownership should not be observed frequently in franchising, or that franchisees who own several units should at least not own clusters of units in given markets, there are also many reasons why franchisors may want multi-unit franchisees and allow them to own sets of geographically clustered units. First, franchisees may possess special expertise in operating units in particular types of markets. In fact, a number of models have proposed franchisees' knowledge of local market conditions as a reason for franchisors to use franchising, specifically considering knowledge of realized local demand (Mathewson and Winter, 1985; Norton, 1988), of consumer tastes (Minkler, 1992), and of unit productivity (Lafontaine and Bhattacharyya, 1995). Further, franchisor executives often mention the high cost of finding high-quality franchisees (Bradach, 1998). Multi-unit franchising in that context may best be viewed as a way for franchisors to use efficiently their existing pool of high-quality, knowledgeable franchisees. Furthermore, the promise of additional units for high-performing franchisees acts as an incentive device in these chains. ${ }^{6}$ The concentration of the franchisee's units in geographically close and demographically similar markets then is especially beneficial as it simultaneously minimizes the costs to the franchisee of monitoring all his units and makes the best possible use of the franchisee's expertise in specific types of markets.

Second, one well-known problem that arises in franchising is that individual franchisees, because they are residual claimants, have incentives to free-ride on the value of the trade name, e.g., by using lower-quality inputs or advertising too little. As noted by Brickley (1999), a franchisee who owns many units, and especially many proximate units, would internalize such externalities to a greater extent, thereby reducing his incentive to free-ride generally. ${ }^{7}$

Third, while some degree of intra-chain competition will tend to enhance franchisor profits, franchisors may want to cluster a franchisee's units to avoid franchisees facing "too much" localized competition, which can be detrimental to a franchisor's relationship with its franchisees. McDonald's, for example, explicitly states that it tries to minimize the intermingling of different franchisees' restaurants because this would give rise to "too much intra-chain competition." ${ }^{8}$ In fact, the issue of encroachment - where franchisees have complained that new units are established "too close" to existing ones and "steal" sales of existing units-has gained a lot of prominence in the United States over the last decade. One solution to this problem has been to allow existing franchisees to own new units opened in markets contiguous to their current ones. ${ }^{9}$

Finally, granting many units in a market to a single franchisee can give rise to production and marketing efficiencies. For example, Darr, Argote, and Epple (1995) find that stores of single-unit franchisees "were not able to benefit from production experience at other stores ... [and so] they were less productive than their counterparts in multiple-store franchises" (p. 1761). From a marketing efficiency perspective, consultants stress that it is "important for franchisees to control

${ }^{5}$ See Thomadsen (forthcoming) for evidence that mergers among McDonald's franchisees can lead to higher prices, more so if the units of the franchisees are closer together. See also Blair and Lafontaine (1999) and Lafontaine and Slade (2001) on the issue of double marginalization in franchising.

${ }^{6}$ Such rewards are especially important in chains like McDonald's that restrict their franchisees' options to invest in other businesses. Note that chains explicitly acknowledge the incentive role played by grants of "expansion rights" (see, e.g., Love, 1986; Kaufmann and Lafontaine, 1994; and Bradach, 1998).

${ }^{7}$ Consistent with this argument, Brickley (1999) finds that area development agreements are significantly more likely to be used by franchisors involved in non-repeat-customer industries.

${ }^{8}$ See Kaufmann and Lafontaine (1994). Recent analyses of pricing in fast food (Kalnins, 2003; Thomadsen, forthcoming) suggest that McDonald's and other chains are quite susceptible to intra-chain competition.

${ }^{9}$ See, for example, Franchise Update, 2nd quarter 1994, Kalnins (2004) and Blair and Lafontaine (forthcoming) for more on this.

(c) RAND 2004. 
the markets that they are in for consistent advertising and promotions." 10 The finding of Bates (1998) that new units of existing franchisees are much more likely to remain in business than new units opened by new franchisees reinforces the idea that existing franchisees who get to open more units tend to be of high quality and that there are efficiencies across their units.

\section{The data and end-of-sample ownership patterns}

- Our main source of data is the 1995 State of Texas Sales and Use Tax Permit Holder Information database, which includes the street addresses of all sales-tax-collecting businesses operating in Texas in 1995. It also provides information on owner identity and the date on which the current owner assumed ownership. Table 1 shows the number of owners and their sizes in 1995 in the seven national fast-food chains we focus on, namely Burger King, Dairy Queen, McDonald's, Pizza Hut, Subway, Taco Bell, and Wendy's, along with a measure of the concentration of ownership, the HHI. It shows that single-unit franchisees owned only $13 \%$ of the 3,616 units of these chains in Texas at that time, or $16 \%$ of their 2,886 franchised units. Overall, the table illustrates well the importance of multi-unit franchisees in these large fast-food chains. Moreover, it shows that McDonald's, Pizza Hut, Taco Bell, and Wendy's all operated corporate units in Texas in 1995, with 53, 347, 227, and 103 units respectively. Burger King operated units corporately in Texas earlier on, but none remained corporate by the end of 1995 . The other chains never had corporate units in Texas.

The 1995 ownership patterns also show clearly the importance of keeping distances low between an owner's units, be it franchisee or franchisor, in the ownership allocation process of these chains. From the address information in the tax files, we assigned longitude and latitude coordinates to each restaurant using a process known as "geocoding" (see the Appendix for details) and then measured the distances between all pairs of units. We found that less than 10 (5) miles separate the two units of 70\% (50\%) of all the two-unit franchisees in these seven chains. Similarly, almost $70 \%$ of the units of large owners-defined as owners with 11 or more units and including franchisors-are within 5 miles of at least one other unit of the same owner. In all, there are only 225 units in the data-out of the 3,146 units owned by multi-unit franchisees or by franchisors - that are more than 30 miles away from the closest other unit of the same owner, and only 60 cases where this distance is more than 60 miles.

TABLE 1 Number of Owners and Their Size in 1995, by Number of Units Owned

\begin{tabular}{lrrrrrrrr}
\hline Size of Owner & $\begin{array}{c}\text { Burger } \\
\text { King }\end{array}$ & $\begin{array}{c}\text { Dairy } \\
\text { Queen }\end{array}$ & McDonald's & $\begin{array}{c}\text { Hizza } \\
\text { Hut }\end{array}$ & Subway & $\begin{array}{c}\text { Taco } \\
\text { Bell }\end{array}$ & Wendy's & $\begin{array}{c}\text { \% of } \\
\text { Owners }\end{array}$ \\
\hline 1 unit & 27 & 168 & 84 & 9 & 164 & 4 & 14 & 51.1 \\
2 units & 23 & 29 & 50 & 2 & 49 & 3 & 2 & 17.2 \\
$3-5$ units & 15 & 31 & 57 & 6 & 60 & 6 & 11 & 20.2 \\
$6-10$ units & 7 & 9 & 19 & 5 & 14 & 3 & 4 & 6.6 \\
$11-20$ units & 5 & 6 & 2 & 2 & 4 & 1 & 1 & 2.3 \\
$21-50$ units & 3 & 5 & 2 & 4 & 0 & 2 & 2 & 2.0 \\
$51-100$ units & 0 & 1 & $1^{*}$ & 0 & 0 & 1 & 0 & .3 \\
$101+$ units & 0 & 0 & 0 & $1^{*}$ & 0 & $1^{*}$ & $1^{*}$ & .3 \\
Total owners & 80 & 249 & 215 & 29 & 291 & 21 & 35 & 100 \\
Total units & 324 & 735 & 673 & 573 & 648 & 402 & 261 & 1,890 \\
HHI & 350 & 230 & 160 & 3,810 & 70 & 3,480 &
\end{tabular}

* Indicates that the owner is the franchisor. See the Appendix for details on defining the relevant set of units and on how we assigned ownership.

${ }^{10}$ Interview with Dennis Lombardi, executive vice president at a restaurant industry research firm, reported in Franklin (2001).

○ RAND 2004. 


\begin{tabular}{|c|c|c|c|c|c|c|c|c|}
\hline \multirow{2}{*}{$\begin{array}{c}\text { Number of } \\
\text { Clusters }\end{array}$} & \multicolumn{8}{|c|}{ Multi-Unit Owner Size } \\
\hline & 2 & $3-5$ & $6-10$ & $11-20$ & $21-50$ & $51-100$ & $101+$ & Total \\
\hline 1 & 107 & 99 & 32 & 6 & 3 & 0 & 0 & 247 \\
\hline 2 & 51 & 60 & 7 & 3 & 6 & 2 & 0 & 129 \\
\hline 3 & 0 & 20 & 12 & 6 & 4 & 0 & 0 & 42 \\
\hline 4 & 0 & 6 & 4 & 0 & 0 & 0 & 0 & 10 \\
\hline 5 & 0 & 1 & 2 & 4 & 1 & 0 & $1^{*}$ & 9 \\
\hline 6 & 0 & 0 & 1 & 1 & 0 & 0 & $1^{*}$ & 3 \\
\hline 7 & 0 & 0 & 2 & 0 & 3 & 0 & 0 & 5 \\
\hline 8 & 0 & 0 & 1 & 1 & 0 & 0 & $1^{*}$ & 3 \\
\hline 15 & 0 & 0 & 0 & 0 & 1 & 0 & 0 & 1 \\
\hline 18 & 0 & 0 & 0 & 0 & 0 & $1^{*}$ & 0 & 1 \\
\hline Total & 158 & 186 & 61 & 21 & 18 & 3 & 3 & 450 \\
\hline
\end{tabular}

${ }^{*}$ Indicates that the owner is the franchisor. There are no owners with 9-14 or 16-17 clusters.

While distance is clearly a major determining factor in the ownership allocation process, some of the costs and benefits of multi-unit ownership noted above arise when franchisees own geographic clusters of units rather than intermingled units. To show the extent to which clustering occurred in these chains by 1995, after all the ownership allocation decisions that we study below have been made, we define a geographic cluster of units as the set of units of any owner that are all neighbors, either directly or indirectly through other units of the same owner. Following West (1981), we define contiguity using Thiessen polygons. The Thiessen polygon around a unit encloses a geographic area within which all points are closer to that unit than to any other unit of the same chain. Thus the polygon's line segments represent points on the map that are equidistant to the two neighbor units defining the segment. (See Figure A1 in the Appendix for an illustration.) Each polygon is by definition convex, and the area covered by all polygons together covers the map completely, without gaps. Given this definition of contiguity, our clusters of neighboring units for an owner can best be understood as geographic surface areas within which a consumer could walk from one unit to another and never go outside the "territory" of an owner.

Table 2 shows how many separate clusters of units the multi-unit owners in our data have, by owner size. Interestingly, most two-unit owners (107 out of 158) own two neighboring units. Perhaps most surprising, however, is the extent to which very large owners own units that belong to just a few clusters: For example, there are only two franchisees with 51-100 units, and both of them have their units clustered in only two groups. Finally, except for McDonald's 18 clusters, franchisors have their large number of units clustered in just a few (5 to 8) groups.

In sum, we find evidence in our 1995 snapshot that the ownership allocation decisions made over time by franchisors have led to franchisees (and franchisors for that matter) owning sometimes quite large sets of units that are both geographically concentrated and clustered. In what follows, we explore how the ownership patterns and other characteristics of franchisees, at the time each unit is allocated, affect the choice of owner. Consistent with our evidence of clusters at the end of our sample period, we find that owning units nearby and contiguous to a new unit increases a franchisee's likelihood of becoming the owner of the new unit. Combined, our results imply that the benefit to franchisors of allowing franchisees to own clusters of units must outweigh the cost.

\section{Ownership allocation decisions over time: model and variables}

- We assess how the ownership of units at the time each decision is made affects franchisors' choices by characterizing the set of units in the market and their owners at each of those points in time. To do this, we use not only the 1995 file of existing businesses described above, but also 
sales tax permit files that contain lists of businesses that have become inactive in the state of Texas because of either ownership transfers or closures. In the end, we can identify the location of all existing units and their owners at the time the franchisor chose the owner of each of the 3,436 new units these chains opened in Texas between 1980 and 1995.

Based on our conversations with franchise managers, and consistent with trade press evidence, we assume that established franchisors choose the locations for their new units and then, given this decision, decide who they want the owners to be. ${ }^{11}$ We do not model the location decision itself, but focus instead on the ownership allocation decision. We model the probability that the franchisor chooses a particular owner for any given location using a nested logit approach. For each unit $i$, we allow the franchisor to choose among any of up to 60 "closest" existing franchisees in Texas at the time unit $i$ becomes available, or opt for a new franchisee or for corporate ownership. ${ }^{12}$ Of the 3,428 units in our final sample, 812 were retained as corporate units, and 702 were allocated to new franchisees. We estimate the franchisor's full decision process, namely the choice between corporate ownership, new, or existing franchisee (the "upper model"), and the choice among existing franchisees (the "lower model"), via full information maximum likelihood. Though estimated simultaneously, we show the results of the lower and upper models separately to facilitate discussion and interpretation. Throughout the article, we use the subscript $i$ to denote simultaneously that we are focusing on unit $i$ and that we are measuring everything at the time unit $i$ becomes available.

Based on the arguments summarized in Section 2, we expect the probability that the franchisor chooses one of the existing franchisees in our lower model to depend on the "match" between that franchisee and the unit, as captured by the extent to which the franchisee's existing units are (1) geographically close to unit $i$, (2) in markets contiguous to unit $i$, and (3) in markets with demographic characteristics similar to unit $i$. We also consider franchisee-specific characteristics that capture the ability level or desirability of assigning new units to this owner.

The measurement of the geographic distance variables for existing franchisees is simple. First, we include as a variable the (natural log of the) minimum Euclidean geographic distance in miles between the new unit $i$ and any of that franchisee's existing units at the time unit $i$ becomes available. ${ }^{13}$ Second, because monitoring activities may be based at headquarters, we include the (natural $\log$ of the) distance between the franchisee's headquarters and the new unit.

As noted earlier, we measure contiguity, or the notion of shared market boundaries, using Thiessen polygons. We sample the polygon in 720 half-degree steps around unit $i$ and use the proportion of such steps for which units of owner $j$ share polygon segments with unit $i$ as our measure of the extent of contiguity between unit $i$ and owner $j$ 's units.

Differences in the demographic characteristics of markets are measured at the zip code level, using data from the 1990 Census. Specifically, we calculate differences in median household income, percentage of blacks, and percentage of the area classified as urban by the U.S. Census Bureau. The demographic distance then is the (absolute value of the) difference between the demographic characteristic in the zip code where unit $i$ is located compared to the zip code in which each of owner $j$ 's units are located. These differences are averaged across all of owner $j$ 's units at the time unit $i$ becomes available.

${ }^{11}$ Managers at Wendy's, Burger King, Dairy Queen, and Subway all told us that the franchisor decides upon a general area (e.g., a group of city blocks) where a new unit would be viable, sometimes based on suggestions of franchisees. They then assign the area to a franchisee, who may be given substantial input into the choice of final location (i.e., the actual building). Still, even this choice is subject to franchisor approval. At McDonald's, franchisees are sometimes offered units in cities other than their own and must move to have the opportunity to open the unit (Kaufmann and Lafontaine, 1994). See also Bradach (1998) on franchisor site approval.

12 We rank existing franchisees from closest to farthest on the basis of the distance of their closest unit to the new unit. For manageability, we exclude from the set of options those owners who are not among the closest 60 based on this ranking. Only eight of the 3,436 units in our data (five Dairy Queens and three Subways) go to existing owners outside the set of closest 60 . These eight units are excluded from our analyses. Results are the same if we keep them and include the chosen owner in the set of options for these units.

${ }^{13}$ All our results remain the same if we use the average distance from owner $j$ 's units to the new unit, or if we use a quadratic functional form for distance variables, or if we include a variable that ranks owners based on distance.

(๑) RAND 2004 


\begin{tabular}{|c|c|c|c|c|}
\hline & Variable Definition & Mean & $\begin{array}{l}\text { Standard } \\
\text { Deviation }\end{array}$ & Maximum \\
\hline \multicolumn{5}{|c|}{ Distance and contiguity variables } \\
\hline Min Distance $_{i j}$ & $\begin{array}{l}\text { Natural } \log \text { of }(1+\text { Euclidean geographical distance between unit } i \\
\text { and franchisee } j \text { 's nearest unit in existence at the time, in miles). }\end{array}$ & 4.51 & 1.15 & 6.63 \\
\hline HQ Distance $_{i j}$ & $\begin{array}{l}\text { Natural } \log \text { of ( } 1+\text { Euclidean geographical distance between unit } i \\
\text { and franchisee } j \text { 's headquarters). }\end{array}$ & 4.71 & 1.18 & 7.72 \\
\hline Contiguity $_{i j}$ & $\begin{array}{l}\text { The proportion of the market boundary around unit } i \text { (defined per a } \\
\text { Thiessen polygon-see Figure A1) associated with franchisee } j \text { 's units. }\end{array}$ & .02 & .09 & 1.00 \\
\hline \multicolumn{5}{|c|}{ Demographic differences variables } \\
\hline$\Delta \%$ of Blacks $_{i j}$ & $\begin{array}{l}\text { Average (absolute value of) differences between \% Blacks in the } \\
\text { zip codes of franchisee } j \text { 's units and this \% in the zip code of unit } i \text {. }\end{array}$ & .12 & .15 & .96 \\
\hline$\Delta \% \operatorname{Urban}_{i j}$ & Average difference in \% Urban, as per above for \% Blacks. & .23 & .25 & 1.00 \\
\hline$\Delta$ Income $_{i j}$ & Average difference in Median Income, as per above for \% Blacks. & .10 & .09 & .65 \\
\hline \multicolumn{5}{|c|}{ Franchisee characteristics } \\
\hline Size $_{i j}$ & Number of units of franchisee $j$ when unit $i$ is opened. & 3.29 & 5.42 & 60.00 \\
\hline Squared Size $_{i j}$ & Squared number of units of franchisee $j$ when unit $i$ is opened. & 40.2 & 199 & 3600 \\
\hline $\begin{array}{l}\text { Years in } \\
\text { Business } i j\end{array}$ & $\begin{array}{l}\text { Years elapsed between franchisee } j \text { 's first unit opening and the } \\
\text { time unit } i \text { is opened. }\end{array}$ & 5.54 & 5.05 & 31.44 \\
\hline $\begin{array}{l}\text { Time Since } \text { Last }_{i j} \\
\text { Same County } \\
i j\end{array}$ & $\begin{array}{l}\text { Years since franchisee } j \text { last opened a unit by the time unit } i \text { is opened. } \\
\text { Binary variable equal to one if franchisee } j \text { owns a unit in the same }\end{array}$ & 3.25 & 3.74 & 31.44 \\
\hline & county as unit $i$. & .12 & .33 & 1.00 \\
\hline $\begin{array}{r}\text { Competition } \\
\text { Intensity } \\
i j\end{array}$ & $\begin{array}{l}\text { Average number of units of the other } 6 \text { chains within } 5 \text { miles of } \\
\text { franchisee } j \text { 's units at the time unit } i \text { is opened. }\end{array}$ & 15.12 & 13.98 & 74.00 \\
\hline
\end{tabular}

Note: Based on 146,837 unit/potential franchisee combinations from 3,428 units. Minima are all zero except for size (=1). The subscript $i$ simultaneously denotes the fact that measures are calculated in relation to unit $i$ (i.e. distances, differences in demographics, etc.) but also that all the measures are defined at the time unit $i$ becomes available.

Finally, to control for differences across franchisees, we include the number of units that each franchisee already has and the number of years since he became involved with the franchised chain. Moreover, we use the number of years since each franchisee last obtained a new unit as a potential inverse measure of his suitability to receive new units. We also include a dummy variable indicating whether the franchisee already owns at least one unit in the county in which unit $i$ is located to capture the possibility that an owner's knowledge of local authorities and ordinances may affect the franchisor's choice of owner for a given unit. Finally, we measure the total number of units of the six other chains that this franchisee competes with on average around his current set of units. This allows for the possibility that franchisees are more or less likely to be chosen depending on the "intensity" of the competition they already face. Table 3 summarizes the variable definitions and shows descriptive statistics across the full set of existing franchisees we consider (thus up to the 60 closest) for all 3,428 units. The number of existing franchisees varies significantly across units, from a low of just 1 (for Subway in 1980) to our imposed maximum of 60 , leading to a total of 146,837 unit/franchisee combinations.

As for the choice between corporate ownership or a new or an existing franchisee (our upper model), we assume that it depends on characteristics of the unit and its market, and on characteristics of the franchisor's units in Texas. Specifically, we relate this decision to the demographic characteristics of the market around unit $i$ (zip code income, percentage of blacks, and percentage urban), and the number of units of other chains within five miles of unit $i$. We also allow distance to corporate units and the extent of contiguity to corporate units, both measured exactly as for existing franchisees, to play a role in the upper model, along with a franchisor "in county" dummy variable. Finally, we include seven new-franchisee dummy variables, one for each chain, and five 
corporate ownership dummy variables (as only five of our seven chains ever have corporate units in Texas). We allow each of the fixed effects and our other variables to have a different effect on the likelihood that the franchisor chooses a new franchisee or corporate ownership. All the coefficients in this part of the model thus should be interpreted relative to the existing franchisee option.

\section{Results}

- Though estimated all at once, in what follows we first discuss results for the choice among existing owners (our lower model). We present results for the choice between corporate, new, and existing franchisee (our upper model) in the next subsection.

$\square \quad$ Choosing among existing franchisees. We show our lower-model regression results for the full sample in the first column of Table 4 . As $64 \%$ of the 1,914 units allocated to existing franchisees go to the owner of the closest unit, variables other than distance in our lower model are perhaps best understood as forces that pull franchisors away from simply allocating each unit to the franchisee with the closest unit. It is therefore of particular interest to see how changes in the attributes of the closest owner affect the likelihood that it and other options are chosen. For that reason, in the next four columns of Table 4, we show how the probability of various options are affected when we change each explanatory variable from its sample minimum to its sample maximum for the closest franchisee option. Following Train (2003), we make the change in attribute at the observation level and then average the effects across observations. We report first the average effect on the probability that the closest franchisee himself is chosen, followed by the sum of the effects for all other existing franchisees, and then the effect for the corporate, and for the new-franchisee option, respectively. By definition, all of these must sum to zero. Finally, for comparison purposes, Table 4 also shows regression results for two subsamples, namely units in rural and in urban areas, while Table 5 presents chain-by-chain results.

Our results clearly imply that franchisors allocate units to franchisees whose existing units and headquarters are geographically close to the new unit being established. The estimates of probability changes in columns 2 and 3 show that the geographic proximity of a franchisee's existing units and headquarters are the most, and the third-most, economically important factors respectively in the choice among existing franchisees. From columns 4 and 5 it is also clear that the distance of the closest franchisee and its headquarters has a sizable positive impact on the likelihood that the franchisor chooses corporate ownership or a new franchisee rather than an existing franchisee.

Our results also show that, controlling for distance, the extent of contiguity has a statistically significant and economically important positive effect on the likelihood that a particular franchisee is selected. Looking back at the raw data, we find 191 units that are entirely surrounded by units belonging to a single franchisee at the time they are opened. Of these, 175 are allocated to this franchisee. Thus franchisors rarely undo franchisee ownership homogeneity in a region even when they have a clear opportunity to do so. Similarly, franchisors choose corporate ownership for 471 of the 489 units fully surrounded by franchisor-owned units.

Our chain-by-chain results in Table 5 show that the distance and contiguity effects in our data are not driven just by those chains that sometimes use area development agreements (in which case a franchisee's units would be necessarily proximate and contiguous). In fact, distance and contiguity play at least as much of a role in the ownership allocation process of chains that do not ever use such agreements as they do for the others. But the fact that our results are similar across chains is important for another reason: our method treats the owner choice for each unit as independent. While we believe this is appropriate for chains that do not use area development agreements, it may not always be for those that do. If used in Texas within the time frame of our sample, such agreements would mean that the franchisor made several of the ownership allocation decisions we focus on all at once. Our standard errors, calculated on the basis of the full set of observations, then would be artificially low. The fact that standard errors are similar for firms that 


\begin{tabular}{|c|c|c|c|c|c|c|c|}
\hline & \multirow[b]{2}{*}{ Overall } & \multicolumn{4}{|c|}{$\begin{array}{l}\text { Overall Effect of Changing Closest Existing on } \\
\text { Prob at Max Minus Prob at Min } \\
\text { (Averaged over Observations) }\end{array}$} & \multicolumn{2}{|c|}{$\begin{array}{l}\text { Subsample Results } \\
\text { Census Definitions }\end{array}$} \\
\hline & & Closest & $\begin{array}{c}\text { All Other } \\
\text { Existing }\end{array}$ & Corporate & New & Rural & Urban \\
\hline \multicolumn{8}{|c|}{ Distance and contiguity variables } \\
\hline Log Min Distance $_{i j}$ & $\begin{array}{c}-1.60^{* *} \\
(.07)\end{array}$ & -.689 & .318 & .121 & .251 & $\begin{array}{c}-1.62^{* *} \\
(.09)\end{array}$ & $\begin{array}{r}-1.51^{* *} \\
(.13)\end{array}$ \\
\hline Log HQ Distance $_{i j}$ & $\begin{array}{l}-.35^{* *} \\
(.04)\end{array}$ & -.246 & .128 & .030 & .088 & $\begin{array}{l}-.41^{* *} \\
(.05)\end{array}$ & $\begin{array}{l}-.29^{* *} \\
(.05)\end{array}$ \\
\hline Contiguity $_{i j}$ & $\begin{array}{l}1.57^{* *} \\
(.22)\end{array}$ & .168 & -.088 & -.021 & -.058 & $\begin{array}{l}1.57^{* *} \\
(.29)\end{array}$ & $\begin{array}{l}1.78^{* *} \\
(.35)\end{array}$ \\
\hline \multicolumn{8}{|c|}{ Demographic differences variables } \\
\hline$\Delta \%$ of Blacks $_{i j}$ & $\begin{array}{c}-1.19^{* *} \\
(.38)\end{array}$ & -.105 & .056 & .011 & .037 & $\begin{array}{r}-1.01 \\
(.60)\end{array}$ & $\begin{array}{r}-1.25^{* *} \\
(.47)\end{array}$ \\
\hline$\Delta \% \operatorname{Urban}_{i j}$ & $\begin{array}{c}-1.11^{* *} \\
(.25)\end{array}$ & -.103 & .055 & .011 & .036 & $\begin{array}{c}-.83^{* *} \\
(.26)\end{array}$ & $\begin{array}{r}-.14 \\
(.65)\end{array}$ \\
\hline$\Delta$ Income $_{i j}$ & $\begin{array}{c}-1.61^{* *} \\
(.58)\end{array}$ & -.097 & .052 & .010 & .034 & $\begin{array}{r}-1.18 \\
(.81)\end{array}$ & $\begin{array}{r}-1.89^{*} \\
(.81)\end{array}$ \\
\hline \multicolumn{8}{|l|}{ Owner characteristics } \\
\hline Same County ${ }_{i j}$ & $\begin{array}{l}.32^{* *} \\
(.12)\end{array}$ & .032 & -.017 & -.004 & -.011 & $\begin{array}{l}.15 \\
(.14)\end{array}$ & $\begin{array}{l}.84^{* *} \\
(.24)\end{array}$ \\
\hline Size $_{i j}$ & $\begin{array}{l}1.25^{* *} \\
(.14)\end{array}$ & .120 & -.059 & -.018 & -.043 & $\begin{array}{l}1.51^{* *} \\
(.16)\end{array}$ & $\begin{array}{c}.49 \\
(.28)\end{array}$ \\
\hline Squared $\operatorname{Size}_{i j}$ & $\begin{array}{c}-.21^{* *} \\
(.03)\end{array}$ & N/A & N/A & N/A & N/A & $\begin{array}{c}-.25^{* *} \\
(.03)\end{array}$ & $\begin{array}{r}-.11^{*} \\
(.05)\end{array}$ \\
\hline Years in Business $i j$ & $\begin{array}{c}-.07^{* *} \\
(.01)\end{array}$ & -.188 & .101 & .021 & .066 & $\begin{array}{c}-.07^{* *} \\
(.01)\end{array}$ & $\begin{array}{r}-.06^{* *} \\
(.02)\end{array}$ \\
\hline Time Since Last $_{i j}$ & $\begin{array}{c}-.21^{* *} \\
(.02)\end{array}$ & -.371 & .195 & .043 & .133 & $\begin{array}{c}-.20^{* *} \\
(.03)\end{array}$ & $\begin{array}{l}-.25^{* *} \\
(.04)\end{array}$ \\
\hline Competitive Intensity $_{i j}$ & $\begin{array}{l}-.03^{* *} \\
(.004)\end{array}$ & -.209 & .113 & .023 & .074 & $\begin{array}{l}-.04^{* *} \\
(.006)\end{array}$ & $\begin{array}{l}-.02^{* *} \\
(.007)\end{array}$ \\
\hline Log-likelihood & $-3,917$ & & & & & $-2,351$ & $-1,532$ \\
\hline Pseudo- $R^{2}$ & .66 & & & & & .67 & .65 \\
\hline Number of units & 3,428 & & & & & 2,001 & 1,427 \\
\hline
\end{tabular}

Standard errors in parentheses.

* Significant at the .05 level.

${ }^{* *}$ Significant at the .01 level.

do and do not use area development agreements, however, suggests that correlated decisions are not a significant problem in our data. ${ }^{14}$

The results for the demographic variables in both tables imply that franchisors favor franchisees who operate in markets with demographic characteristics similar to those of the new unit: all statistically significant coefficients of the demographic-difference variables are negative. The probability changes in Table 4 show that as the demographic distance of the closest franchisee goes from its minimum to its maximum value, the probability of choosing the closest franchisee goes down by about 10 percentage points. These effects are consistent with the chains' desire to "specialize" franchisees to areas with similar types of customers. We also find that already owning units in a county increases the likelihood a franchisee is chosen for a new unit in that

${ }^{14}$ Unobservable characteristics could also lead to correlated decisions within geographic areas and thus to reported standard errors that are too low. Following Cressie (1991), we estimated all regressions with samples that included only one unit, chosen randomly, per zip code for each chain. The results for the distance and contiguity variables and for franchisee characteristics remained qualitatively the same, while the demographic variables showed marginally weaker effects.

(c) RAND 2004. 


\begin{tabular}{|c|c|c|c|c|c|c|c|}
\hline & \multicolumn{4}{|c|}{ Chains Not Using Area Development Agreements } & \multicolumn{3}{|c|}{ Chains with Area Development Agreements } \\
\hline & Burger King & McDonald's & Subway & Wendy's & Dairy Queen & Pizza Hut & Taco Bell \\
\hline \multicolumn{8}{|c|}{ Distance and contiguity variables } \\
\hline Log Min Distance $_{i j}$ & $\begin{array}{c}-1.27^{* *} \\
(.21)\end{array}$ & $\begin{array}{c}-2.14^{* *} \\
(.21)\end{array}$ & $\begin{array}{c}-1.63^{* *} \\
(.14)\end{array}$ & $\begin{array}{c}-1.06^{* *} \\
(.26)\end{array}$ & $\begin{array}{c}-1.42^{* *} \\
(.16)\end{array}$ & $\begin{array}{c}-1.22^{* *} \\
(.26)\end{array}$ & $\begin{array}{c}-2.21^{* *} \\
(.38)\end{array}$ \\
\hline Log HQ Distance $_{i j}$ & $\begin{array}{c}-.30^{* *} \\
(.10)\end{array}$ & $\begin{array}{c}-.41^{* *} \\
(.09)\end{array}$ & $\begin{array}{c}-.48^{* *} \\
(.08)\end{array}$ & $\begin{array}{r}-.15 \\
(.15)\end{array}$ & $\begin{array}{c}-.31^{* *} \\
(.10)\end{array}$ & $\begin{array}{r}-.32 * \\
(.15)\end{array}$ & $\begin{array}{c}-.56^{* *} \\
(.21)\end{array}$ \\
\hline Contiguity $_{i j}$ & $\begin{array}{c}4.54^{* *} \\
(.73)\end{array}$ & $\begin{array}{r}1.12 * \\
(.53)\end{array}$ & $\begin{array}{c}.34 \\
(.42)\end{array}$ & $\begin{array}{c}3.10^{* *} \\
(.97)\end{array}$ & $\begin{array}{l}2.24^{* *} \\
(.49)\end{array}$ & $\begin{array}{c}1.95 \\
(1.04)\end{array}$ & $\begin{array}{c}.98 \\
(1.03)\end{array}$ \\
\hline \multicolumn{8}{|c|}{ Demographic differences variables } \\
\hline$\Delta \%$ of Blacks $i j$ & $\begin{array}{r}-.38 \\
(.80)\end{array}$ & $\begin{array}{c}-1.97^{* *} \\
(.69)\end{array}$ & $\begin{array}{r}-1.54 \\
(.80)\end{array}$ & $\begin{array}{r}-1.94 \\
(2.59)\end{array}$ & $\begin{array}{l}-.16 \\
(1.10)\end{array}$ & $\begin{array}{c}.66 \\
(2.65)\end{array}$ & $\begin{array}{c}4.43 \\
(2.58)\end{array}$ \\
\hline$\Delta \% \operatorname{Urban}_{i j}$ & $\begin{array}{r}-1.09 \\
(1.01)\end{array}$ & $\begin{array}{c}-2.16^{* *} \\
(.79)\end{array}$ & $\begin{array}{r}-.48 \\
(.55)\end{array}$ & $\begin{array}{c}.76 \\
(2.28)\end{array}$ & $\begin{array}{c}-1.20^{* *} \\
(.38)\end{array}$ & $\begin{array}{c}1.02 \\
(1.07)\end{array}$ & $\begin{array}{r}-2.86 \\
(1.53)\end{array}$ \\
\hline$\Delta$ Income $_{i j}$ & $\begin{array}{r}-1.25 \\
(1.51)\end{array}$ & $\begin{array}{l}-.87 \\
(1.26)\end{array}$ & $\begin{array}{r}-1.75^{*} \\
(.89)\end{array}$ & $\begin{array}{c}1.88 \\
(2.36)\end{array}$ & $\begin{array}{r}-3.53 \\
(1.85)\end{array}$ & $\begin{array}{c}-11.5^{* *} \\
(3.44)\end{array}$ & $\begin{array}{r}-3.05 \\
(3.61)\end{array}$ \\
\hline \multicolumn{8}{|c|}{ Franchisee characteristics } \\
\hline Same County ${ }_{i j}$ & $\begin{array}{c}.03 \\
(.38)\end{array}$ & $\begin{array}{c}.16 \\
(.32)\end{array}$ & $\begin{array}{c}.23 \\
(.21)\end{array}$ & $\begin{array}{c}.59 \\
(.53)\end{array}$ & $\begin{array}{c}.42 \\
(.24)\end{array}$ & $\begin{array}{c}.95 \\
(.57)\end{array}$ & $\begin{array}{r}-1.42^{*} \\
(.66)\end{array}$ \\
\hline Size $_{i j}$ & $\begin{array}{r}-.60 \\
(.94)\end{array}$ & $\begin{array}{r}-.26 \\
(.57)\end{array}$ & $\begin{array}{l}2.69^{* *} \\
(.77)\end{array}$ & $\begin{array}{l}1.04 \\
(.82)\end{array}$ & $\begin{array}{l}2.19^{* *} \\
(.24)\end{array}$ & $\begin{array}{c}.79 \\
(.73)\end{array}$ & $\begin{array}{r}-.47 \\
(.58)\end{array}$ \\
\hline Squared Size $_{i j}$ & $\begin{array}{c}.30 \\
(.35)\end{array}$ & $\begin{array}{c}.13 \\
(.21)\end{array}$ & $\begin{array}{r}-1.51^{*} \\
(.61)\end{array}$ & $\begin{array}{r}-.21 \\
(.30)\end{array}$ & $\begin{array}{c}-.40^{* *} \\
(.04)\end{array}$ & $\begin{array}{r}-.17 \\
(.24)\end{array}$ & $\begin{array}{c}.18 \\
(.11)\end{array}$ \\
\hline Years in Business ${ }_{i j}$ & $\begin{array}{r}-.07^{*} \\
(.03)\end{array}$ & $\begin{array}{r}-.02 \\
(.02)\end{array}$ & $\begin{array}{c}-.15^{* *} \\
(.05)\end{array}$ & $\begin{array}{r}-.15^{*} \\
(.07)\end{array}$ & $\begin{array}{c}-.12^{* *} \\
(.02)\end{array}$ & $\begin{array}{c}-.09^{* *} \\
(.03)\end{array}$ & $\begin{array}{r}-.02 \\
(.04)\end{array}$ \\
\hline Time Since Last $i j$ & $\begin{array}{c}-.34^{* *} \\
(.08)\end{array}$ & $\begin{array}{r}-.08^{*} \\
(.04)\end{array}$ & $\begin{array}{c}-.19^{* *} \\
(.07)\end{array}$ & $\begin{array}{r}-.16 \\
(.12)\end{array}$ & $\begin{array}{c}-.30^{* *} \\
(.05)\end{array}$ & $\begin{array}{c}-.43^{* *} \\
(.14)\end{array}$ & $\begin{array}{c}-.32^{* *} \\
(.11)\end{array}$ \\
\hline $\begin{array}{l}\text { Competitive } \\
\text { Intensity }{ }_{i j}\end{array}$ & $\begin{array}{l}-.03^{*} \\
(.013)\end{array}$ & $\begin{array}{c}-.03^{* *} \\
(.01)\end{array}$ & $\begin{array}{l}-.03^{* *} \\
(.006)\end{array}$ & $\begin{array}{r}-.04 \\
(.02)\end{array}$ & $\begin{array}{c}-.03^{* *} \\
(.01)\end{array}$ & $\begin{array}{r}-.02 \\
(.03)\end{array}$ & $\begin{array}{r}-.06^{*} \\
(.03)\end{array}$ \\
\hline Log-likelihood & -383.7 & -870.5 & $-1,287.8$ & -175.6 & -696.2 & -147.2 & -160.0 \\
\hline Pseudo- $R^{2}$ & .68 & .64 & .50 & .75 & .71 & .89 & .85 \\
\hline Number of units & 326 & 635 & 710 & 235 & 583 & 554 & 385 \\
\hline
\end{tabular}

Standard errors in parentheses.

* Significant at the .05 level.

${ }^{* *}$ Significant at the .01 level.

county-except at Taco Bell. This positive effect may partially capture a distance effect again, especially since this effect is particularly strong in the urban subsample, or it may represent the advantage a franchisee has in dealing with familiar local authorities. Together, the results for the demographic characteristics and the "present in county" variable all support the idea that franchisors pay attention to franchisees' knowledge of specific types of markets.

New units also are more likely to be allocated to larger franchisees, though this effect decreases with size as per the coefficient on size squared. All else constant, a franchisee size of 20 to 30 units maximizes the likelihood of receiving additional units. As this optimal size is quite large relative to actual franchisee holdings (see Table 1), the effect of size is positive for most franchisees and probably captures franchisee quality, as better owners are simultaneously likely to be larger and allowed to expand further. Controlling for the number of units a franchisee has, those that have been in the system longer are less likely to be chosen to own a new unit. This suggests that franchisees become less "valuable" with age, possibly because of impending retirement and the uncertainty this gives rise to. In addition, franchisees who have received no units for a long time are less likely to receive new units. This may mean that such franchisees are 
less qualified, and so franchisors choose to not give them new units, or that they simply do not desire new units. Finally, the number of competitors that a franchisee faces on average around his existing units decreases the likelihood that he will be given additional units. This result, and the smaller effect of owner size in urban areas, is consistent with the idea that a franchisee's work is more demanding in more competitive environments.

It is important to note that the results above are very robust. They remained the same across various subsamples (e.g., different time periods), specifications (e.g., restricting or expanding the set of existing owners), and measures (including alternative distance, contiguity, and demographic variables). Moreover, we constructed a variety of measures of specific cross-chain competitive effects, but none of these proved important in the ownership allocation process other than the effect of overall competitive intensity at a franchisee's existing locations discussed above. ${ }^{15} \mathrm{We}$ conclude that factors that affect the desirability of individual owners relate mostly to within-chain considerations, including franchisee quality and the characteristics of the markets they operate in already, and the desire to keep distances low for efficiency purposes.

․ The choice among corporate, new, and existing franchisee. Results concerning the decision to use corporate ownership versus a new versus an existing franchisee-our upper model-are summarized in Table 6 . We show the effect of each of the variables on the choice of corporate ownership in the full sample and in the rural and the urban subsamples in columns 1 through 3 . This is followed by the effects of the same variables for the same samples but interacted instead with the new-franchisee option in columns 4 to 6 .

Most importantly, the results in Table 6 establish that distance to corporate units, contiguity with corporate units, and existing corporate presence in a county all have a large and usually significant effect on the probability that the franchisor will choose corporate ownership rather than an existing franchisee, and that these effects go in the same direction for the corporate decision as for the choice among existing franchisees. In fact, we obtained very similar results to those shown in Table 4 when we included the corporate option among the set of existing franchisees. We conclude that franchisors use similar decision rules, especially in terms of geographic patterns, when deciding to retain units for corporate ownership as they do when choosing among franchisees.

This result that franchisors choose similar geographic patterns for their units as for those of their franchisees is interesting given that some of the franchising literature and the trade press suggest instead that franchisors pursue different goals and apply different criteria when choosing to retain units for themselves. Martin (1988), for example, along with much of the popular press on franchising, has suggested that franchisors keep the most profitable and least risky units for themselves, regardless of the relative location of other company-owned units. Minkler (1990), on the other hand, has argued that franchisors systematically intersperse their units with those of franchisees in order to learn from franchisees. Similarly, vertical separation arguments for franchising (Hadfield, 1991; Baye, Crocker, and Ju, 1996) imply that all units should act as independent profit-maximizing centers. Thus, units belonging to a single entity, franchisor or franchisee, should be intermingled with those of other owners to be aggressive enough to prevent entry (Hadfield's argument), or capture a larger share of the market (Baye, Crocker, and Ju). Our results suggest instead that franchisors locate their units proximately and contiguously, pursuing the same efficiencies they allow their franchisees to benefit from. In fact, Bradach (1998, p. 53) reports being told by chain managers that "big franchisees look just like us" and notes that multi-unit franchisees even mimic the regional management structures of franchisors' corporate operations.

Results in Table 6 imply that franchisors also use new owners more often in areas with many neighboring corporate units. Combined with the positive effect of corporate contiguity on the likelihood of corporate ownership, the implication is that the presence of several corporate neighbors reduces significantly the probability that a unit will go to an existing franchisee.

\footnotetext{
${ }^{15}$ In particular, we experimented with variables capturing familiarity with the owners who will compete with the new unit, by chain and in total, and with measures of the difference in market composition around an owner's units and the market surrounding the new unit $i$, by chain and in total, but none of these performed well in the regressions.

(c) RAND 2004.
} 


\begin{tabular}{|c|c|c|c|c|c|c|}
\hline \multirow[b]{2}{*}{ Interaction with: } & \multicolumn{3}{|c|}{ Corporate Ownership } & \multicolumn{3}{|c|}{ New Franchisee } \\
\hline & Full Sample & Rural & Urban & Full Sample & Rural & Urban \\
\hline \multirow[t]{2}{*}{ Distance to Corporate Unit } & $-.68^{* *}$ & $-.60^{* *}$ & $-.81^{* *}$ & .04 & .10 & -.07 \\
\hline & $(.14)$ & $(.17)$ & $(.28)$ & $(.08)$ & $(.10)$ & $(.19)$ \\
\hline \multirow[t]{2}{*}{ Corporate Contiguity } & $1.97^{* *}$ & $2.89^{* *}$ & .86 & $1.30^{* *}$ & $1.74^{* *}$ & .64 \\
\hline & $(.40)$ & $(.59)$ & $(.60)$ & $(.40)$ & $(.62)$ & $(.56)$ \\
\hline \multirow[t]{2}{*}{ Corporate in County } & $1.35^{* *}$ & $1.14^{* *}$ & 1.40 & .41 & .40 & .83 \\
\hline & $(.33)$ & $(.38)$ & $(.79)$ & $(.30)$ & $(.38)$ & $(.60)$ \\
\hline \multirow[t]{2}{*}{ Zip Median Income } & .64 & 1.16 & -.42 & .62 & 1.31 & -.31 \\
\hline & $(.54)$ & $(1.36)$ & $(1.19)$ & $(.54)$ & $(.79)$ & $(.79)$ \\
\hline \multirow[t]{2}{*}{ Zip \% Black } & -.57 & -.27 & -.99 & $1.00^{*}$ & $1.74^{* *}$ & .28 \\
\hline & $(.61)$ & $(1.30)$ & $(.75)$ & $(.40)$ & $(.66)$ & $(.53)$ \\
\hline \multirow[t]{2}{*}{ Zip \% Urban } & .53 & & & $.98^{* *}$ & & \\
\hline & $(.50)$ & & & $(.24)$ & & \\
\hline Number of Competitors & .01 & .03 & -.001 & $.02^{* *}$ & $.025^{*}$ & .01 \\
\hline within 5 miles & $(.01)$ & $(.02)$ & $(.01)$ & $(.005)$ & $(.01)$ & $(.007)$ \\
\hline Chain Dummy Variables & 5 of them $* *$ & 5 of them ${ }^{* *}$ & 5 of them ${ }^{* *}$ & 7 of them ${ }^{* *}$ & 7 of them ${ }^{* *}$ & 7 of them ${ }^{* *}$ \\
\hline
\end{tabular}

Standard errors in parentheses.

* Significant at the .05 level.

** Significant at the .01 level.

The results for the demographic characteristics of the market around the new unit imply that, relative to the existing franchisee options, franchisors are more likely to choose a new franchisee than either an existing franchisee or corporate ownership in largely black and in urban communities, and in areas where other chains have already established many units. The result regarding new franchisees and the proportion of blacks may be due to franchisors' attempts to increase the number of minority owners. However, it is also consistent with complaints by minority franchisees that they are not allowed to expand as much as they would like (e.g., Weil, 1999).

The relationships between new franchisee and urban locations, and locations with many units of competing chains, are consistent with at least three explanations. First, there might be a lower supply of qualified new franchisees available to operate rural units. The chains in our analyses, however, attract fairly large numbers of potential franchisees and often ask candidates to relocate to take possession of a first unit. Second, urban markets may exhibit fewer local quirks, and, as such, it may be less imperative that an existing owner with local knowledge operate new urban units. Third, we found earlier that owners with units in more competitive markets were less likely to be given new units. If this were due to the greater difficulty of managing units in such markets, it would imply a smaller optimal franchisee size and thus an increased reliance on new franchisees in these markets.

Finally, the coefficients of the interacted chain dummies for corporate ownership and new franchisees are all individually statistically significant and negative in our overall sample, with the majority remaining statistically significant in our subsamples as well. The new-franchisee coefficients are all larger in absolute terms than their counterpart for the corporate option, significantly so for three of the five chains with corporate units. These results imply that all else equal, the franchisors in our data are more likely to choose existing franchisees than corporate ownership, which, in turn, most of them are more likely to choose than the new-franchisee option.

\section{Conclusion}

- The goal of this article was to show the extent of multi-unit ownership in franchised chains, and to explore factors that affect franchisors' decisions to allocate the ownership of individual units to particular owners. We find strong evidence in the data, in both the 1995 distribution of units (c) RAND 2004 
among owners described in Section 3 and in the ownership allocation decisions made over time, that the established franchisors in our data (1) frequently use multi-unit franchisees, (2) allow their multi-unit franchisees to own units that are close to one another and share market boundaries, in ways similar to what they do with their company-owned units, and (3) favor franchisees with relevant experience in markets with similar demographic characteristics.

Overall, our results strongly suggest that within-chain incentive and efficiency issues, not cross-chain considerations, drive the ownership allocation decisions in these chains. Specifically, the fact that franchisors prefer existing franchisees to corporate ownership and new franchisees generally, and grant even more units - up to a point where decreasing returns take effect-to those franchisees who already have many, imply that the potential incentive cost associated with the separation of ownership and control under multi-unit ownership is outweighed, in the eyes of franchisors, by the efficiency and incentive benefits associated with the same. Our finding that proximity and contiguity both contribute positively to the likelihood a franchisee is selected suggests that the efficiency benefits associated with allowing franchisees to own clusters of units also must outweigh the cost that might arise from the lack of "aggressive" strategic behavior or the increased bargaining or market power that owners of clusters of units might exert on their franchisor. Instead, franchisors' decisions seem to minimize the costs franchisees incur to monitor their managers by offering them close-by units and units that operate in similar types of markets. Further, they minimize encroachment problems and high intra-brand competition, for which contiguity matters separately from distance. Limiting intermingling has the added advantage of increasing the likelihood that the units of a franchisee serve the same customer base, making it an effective way to curb free-riding problems. Finally, our finding that demographic similarity also matters again points to the franchisor's desire to fully utilize his franchisees' knowledge and capabilities as the basic function of multi-unit ownership in these markets.

\section{Appendix}

- We explain our sample, measurement issues, and geocoding methods below.

Our unit data contains 5,307 distinct records, reflecting the ownership history of 3,980 unit locations. Of these, 3,616 are in operation at the end of 1995 (see Table 1). We only include a unit in our empirical analyses the first time it is assigned to an owner, and only if the date of this assignment is in 1980 or later. This gives rise to our final sample of 3,428 units.

We assign ownership based on owner name. However, we found in the tax file several corporations with different names but the same address (we found 200 such addresses), where each corporation could own several restaurants. Given the importance of not putting together in our analyses units that do not belong to the same owner, we only assigned units from different corporations to the same owner when it was clear that they belonged to the same individual or group of individuals (for example, "BRUCE TIDWELL" and "BRUCE TIDWELL CORPORATION"). In the end, we identified 1,263 distinct owners in the data, 920 of whom owned units still in operation at the end of 1995.

There was only one instance in the data where the same owner, Town and Country Food Stores, owned units from two chains, namely six Subways and two Taco Bells. This owner is a chain of convenience stores that operates the units under co-branding agreements. It also operates several gasoline stations under different brands. Given that this type of "cross-chain ownership" occurred only once in our data, we "created" a separate owner in each chain for these units, and ignored the issue of cross-chain ownership in the article.

Measuring distances and contiguity in our data depends critically on our capacity to pinpoint location precisely. We were able to pinpoint the location of the vast majority of the units very precisely, based on either actual street number or nine-digit zip code. For those cases where the geocoding routines returned ambiguous or zip centroid matches, we researched their locations individually using a variety of mapping websites to obtain accurate longitude and latitude coordinates.

The census file STF 3B contains demographic data for 1,633 zip codes in Texas. Unfortunately, these do not include all of the zip codes in which the restaurants were located according to the sales tax file. In some cases the zip codes in the tax file were simply miskeyed. In other cases, the restaurant appears in a zip code that was created after 1990. The geocoding process provided us with an "official postal service zip code," but many of these zip codes also did not exist at the time of the Census in 1990. Moreover, zip code boundaries change over time. To get zip codes we could match with the Census data, we started from the zip code information available in our data files the first time we observe a unit (earliest as possible after 1990). We used this zip code if it was among the 1,633 zip codes in Texas in 1990. Otherwise, we used the distance from the unit to zip code centroids and information about the city, both from the Gazetteer database published by Delorme Co. (in 1990) to determine the best zip code to use.

(c) RAND 2004. 


\section{FIGURE A1}

\section{A THIESSEN POLYGON}

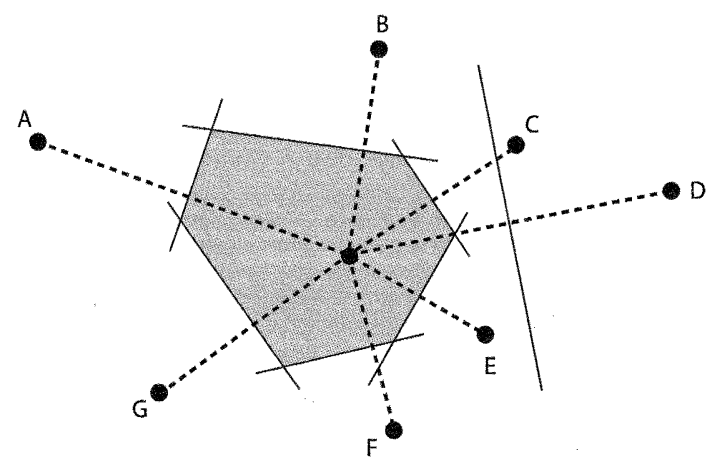

Figure A1 illustrates the process of defining a Thiessen polygon and a unit's neighbors. As shown, units A, B, C, $\mathrm{E}, \mathrm{F}$, and $\mathrm{G}$ are all contiguous (or neighbors) to the middle unit, but unit $\mathrm{D}$ is not. Also, units $\mathrm{A}$ and $\mathrm{D}$ are at the same distance from the middle unit. Hence, examining whether contiguity matters given distance amounts to asking whether a unit such as the middle unit is more (or less) likely to be owned by the owner of unit A than by the owner of unit D. Note that Thiessen polygons for units at the edge of the map are open, as there are no adjacent units beyond the edge.

\section{References}

Azoulay, P. and Shane, S. "Entrepreneurs, Contracts, and the Failure of Young Firms." Management Science, Vol. 47 (2001), pp. 337-358.

Bates, T. "Survival Patterns Among Newcomers to Franchising." Journal of Business Venturing, Vol. 13 (1998), pp. $113-130$.

Baye, M.R., Crocker, K.J., AND Ju, J. “Divisionalization, Franchising, and Divestiture Incentives in Oligopoly.” American Economic Review, Vol. 86 (1996), pp. 223-236.

Blair, R. and Lafontaine, F. "Will Khan Foster or Hinder Franchising? An Economic Analysis of Maximum Resale Price Maintenance." Journal of Public Policy in Marketing, Vol. 18 (1999), pp. 25-36.

- TND Economics of Franchising. New York: Cambridge University Press, forthcoming.

Bradach, J.L. Franchise Organizations. Cambridge, Mass.: Harvard Business School Press, 1998.

Brickley, J.A. "Incentive Conflicts and Contracting: Evidence from Franchising." Journal of Law and Economics, Vol. 42 (1999), pp. 745-774.

Cressie, N.A.C. Statistics for Spatial Data. New York: Wiley, 1991.

Darr, E.D., Argote, L., And EpPle, D. "The Acquisition, Transfer, and Depreciation of Knowledge in Service Organizations: Productivity in Franchises.” Management Science, Vol. 41 (1995), pp. 1750-1762.

FranCHISE UPDATE, 2nd quarter 1994 (Special Issue on Encroachment).

Franklin, J. “Ailing Chain Struggles to Find Ultimate Cure-All." Franchise Times, Vol. 7 (2001), pp. 14-15.

$\rightarrow$ Hadfield, G. "Credible Spatial Pre-emption Through Franchising." RAND Journal of Economics, Vol. 22 (1991), pp. 531-543.

Kalnins, A. "Hamburger Prices and Spatial Econometrics.” Journal of Economics and Management Strategy, Vol. 12 (2003), pp. 591-616.

- . "An Empirical Analysis of Territorial Encroachment Within Franchised and Company-Owned Branded Chains." Marketing Science, Vol. 23 (2004), pp. 476-489.

Kaufmann, P.J. And Dant, R.P. "Multi-Unit Franchising: Growth and Management Issues.” Journal of Business Venturing, Vol. 11 (1996), pp. 343-358.

- AND KIM, S.H. "Master Franchising and System Growth Rates." In P.J. Kaufman and R.P. Dant, eds., Franchising: Contemporary Issues and Research. New York: Haworth Press, 1995.

$\rightarrow$ and Lafontaine, F. "Costs of Control: The Source of Economic Rents for McDonald's Franchisees." Journal of Law and Economics, Vol. 37 (1994), pp. 417-453.

- Donthu, N., AND Brooks, C.M. "Multi-Unit Retail Site Selection Processes: Incorporating Opening Delays and Unidentified Competition." Journal of Retailing, Vol. 76 (2000), pp. 113-127.

Lafontaine, F. and Bhattacharyya, S. "The Role of Risk in Franchising." Journal of Corporate Finance, Vol. 2 (1995), pp. 39-74.

- and Slade, M.E. "Incentive Contracting and the Franchise Decision." In K. Chatterjee and W. Samuelson, eds., Game Theory and Business Applications. Boston: Kluwer Academic Press, 2001.

Love, J.F. McDonald's: Behind the Arches. New York: Bantam Books, 1986.

LUTZ, N.A. "Ownership Rights and Incentives in Franchising." Journal of Corporate Finance, Vol. 2 (1995), pp. 103-130.

○ RAND 2004. 
MaRTIN, R.E. "Franchising and Risk Management.” American Economic Review, Vol. 78 (1988), pp. 954-968.

Mathewson, G.F. And Winter, R.A. "The Economics of Franchise Contracts.” Journal of Law and Economics, Vol. 28 (1985), pp. 503-526.

MCDONALD'S CORPORATION. Franchise Agreement: Uniform Franchise Offering Circular, Exhibit A. OAK BrooK: ILL., 2003.

MCLAMORE, J.W. The Burger King: Jim McLamore and the Building of an Empire. New York: McGraw-Hill, 1998.

MinKLER, A.P. "An Empirical Analysis of a Firm's Decision to Franchise.” Economics Letters, Vol. 34 (1990), pp. 77-82. - "Why Firms Franchise: A Search Cost Theory." Journal of Institutional and Theoretical Economics, Vol. 148 (1992), pp. 240-259.

Norton, S.W. "An Empirical Look at Franchising as an Organizational Form.” Journal of Business, Vol. 61 (1988), pp. $197-218$.

ThOMADSEN, R. "The Effect of Ownership Structure on Prices in Geographically Differentiated Industries.” RAND Journal of Economics, forthcoming.

Train, K.E. Discrete Choice Methods with Simulation. New York: Cambridge University Press, 2003.

WEIL, J. "KFC and Black Franchisees Spar over Dallas Expansion." Wall Street Journal, September 22, 1999, p. T1.

$\rightarrow$ WEST, D.S. "Testing for Market Preemption Using Sequential Location Data." Bell Journal of Economics, Vol. 12 (1981), pp. 129-143. 